\title{
Induction of defense enzymes and control of anthracnose in cucumber by Corymbia citriodora aqueous extract
}

\author{
Gilmar Franzener ${ }^{1}$, Kátia Regina Freitas Schwan-Estrada², Gabriela Silva Moura ${ }^{1}$, Odair José Kuhn , José Renato \\ Stangarlin ${ }^{3}$
}

${ }^{1}$ Universidade Federal da Fronteira Sul (UFFS), BR 158, km 405, CEP 85301970, Laranjeiras do Sul-PR; ${ }^{2}$ Universidade Estadual de Maringá (UEM), Av. Colombo, 5790, CEP 87020200, Maringá, PR; ${ }^{3}$ Universidade Estadual do Oeste do Paraná (UNIOESTE), Rua Pernambuco, 1777, CEP 85960000, Marechal Cândido Rondon, PR.

Autor para correspondência: Gilmar Franzener (gilmar.franzener@uffs.edu.br)

Data de chegada: 19/02/2016. Aceito para publicação em: 20/06/2017.

$10.1590 / 0100-5405 / 2218$

\section{ABSTRACT}

Franzener, G.; Schwan-Estrada, K.R.F.; Moura, G.S.; Kuhn, O.J.; Stangarlin, J.R. Induction of defense enzymes and control of anthracnose in cucumber by Corymbia citriodora aqueous extract. Summa Phytopathologica, v.44, n.1, p.10-16, 2018.

Secondary compounds of medicinal plants can activate defense mechanisms in plants against pathogens. The aqueous extract (AE) of Corymbia citriodora has shown that activity, but there is scarce information about the involved mechanisms of action. Therefore, this study aimed to evaluate the effect of AE on the induction of defense enzymes and protection of cucumber from Colletotrichum lagenarium. Thus, the AE, autoclaved or not, was evaluated for its capability of protecting and inducing peroxidases, polyphenoloxidases, chitinases and $\beta-1.3$-glucanases, and phenylalanine ammonia-lyase. Distilled water and acibenzolar-S-methyl (50 mg a.i. $\left.\mathrm{L}^{-1}\right)$ were used as controls. The effect of $\mathrm{AE}$ at the concentrations of $1,5,10$,
15 and $20 \%$ was also evaluated, as well as its local and systemic effect, and the effect of one or two applications. Pathogen inoculation or sample collection for determination of enzyme activity was performed at 72 hours after treatments. The AE reduced the severity of $C$. lagenarium and induced peroxidases and $\beta-1.3$-glucanases by $37.6,67.2$ and $122.7 \%$, respectively. There was a reduction in the disease severity and an increase in peroxidases from the concentration of 5\% AE. The latter showed only local effect and greater reduction in severity when two applications were performed. These results suggest the effect of $\mathrm{AE}$ in inducing resistance in cucumber and inducing peroxidases and $\beta$-1.3-glucanases.

Keywords: Resistance induction, alternative control, medicinal plant.

\section{RESUMO}

Franzener, G.; Schwan-Estrada, K.R.F.; Moura, G.S.; Kuhn, O.J.; Stangarlin, J.R. Indução de enzimas de defesa e controle de antracnose em pepino por extratos aquosos de Corymbia citriodora aqueous extract. Summa Phytopathologica, v.44, n.1, p.10-16, 2018.

Compostos secundários de plantas medicinais podem ativar mecanismos de defesa em plantas contra patógenos. O extrato aquoso (EA) de Corymbia citriodora têm manifestado essa atividade, mas são escassas informações dos mecanismos de ação envolvidos. Assim, esse trabalho teve por objetivo avaliar o efeito do EA na indução de enzimas de defesa e na proteção de pepino à Colletotrichum lagenarium. Para tanto, o EA, autoclavado ou não, foi avaliado quanto a capacidade de proteção e indução de peroxidases, polifenoloxidases, quitinases e b-1,3 glucanases e fenilalanina amônialiase. Água destilada e acibenzolar-S-metil ( $50 \mathrm{mg}$ i.a. $\left.\mathrm{L}^{-1}\right)$ foram utilizados como testemunhas. Também foi avaliado o efeito do EA nas concentrações de $1,5,10,15$ e $20 \%$, bem como o efeito local e sistêmico, e de uma ou duas aplicações. A inoculação do patógeno ou a coleta de amostras para determinação da atividade enzimática foi realizada 72 horas após os tratamentos. O EA reduziu a severidade de $C$. lagenarium e induziu peroxidases e $\beta$-1,3-glucanases em 37,6, 67,2 e 122,7\%, respectivamente. Houve redução na severidade da doença e aumento de peroxidases a partir da concentração de 5\% do EA. Este apresentou somente efeito local, com maior redução na severidade quando em duas aplicações. Estes resultados sugerem o efeito indutor de resistência do EA em pepino com indução de peroxidases e $\beta$-1,3-glucanases.

Palavras-chave: Indução de resistência, controle alternativo, planta medicinal.

Control of plant diseases has been largely achieved with the use of pesticides. This form of control often faces the emergence of pathogen strains that are resistant to chemicals used for contamination problems and ecological imbalance. In addition, sustainability, food security and environmental protection become a necessity, as well as guidelines for agricultural production. In this context, alternative control of plant diseases have been studied $(5,24)$.

One alternative control line that has been shown very promising studies the use of secondary plant metabolites (11) that can induce resistance in plants, representing an important alternative for the management of diseases $(21,28)$.

Resistance induction in plants consists in activating latent defense mechanisms by means of localized infection by pathogens or as a response to treatment with different biotic agents (such as viable or inactivated micro-organisms) or abiotic factors $(18,19,20)$.

A large number of enzymes are associated with induced resistance (17), such as peroxidases, polyphenol oxidases, phenylalanine ammonia lyase, $\beta$-1,3-glucanases and chitinases. B-1,3-glucans and chitinases 
are PRPs that degrade the cell walls of pathogens, releasing molecules that act as elicitors in the initial stages of the resistance induction process on phytoalexins and phenolic compounds (23). Peroxidases play a fundamental role in the growth and development of plants and are strongly related to defense mechanisms against pathogens $(1,14$, 15). Polyphenol is generally abundant in infected tissues and is very important for plants since it is involved in defense mechanisms or in senescence. Phenylalanine ammonia-lyase (PAL) is an enzyme widely studied by physiologists due to its key importance in the secondary metabolism of plants, especially in the synthesis of plant defense compounds (11).

Medicinal plants can have a large number of secondary metabolites with biological activity in their composition (21). The aqueous crude extract or the essential oil of these plants have shown potential to control plant pathogens, either by direct fungitoxic activity or by activating defense mechanisms in the plants $(3,23)$.

Among the pathosystems that have received attention in studies of this nature, anthracnose caused by Colletotrichum lagenarium (Pass) Ellis \& Halsted in cucumber is highlighted (10). Some authors consider peroxidase accumulation in cucumber a biochemical marker of induced resistance in this culture (6).

Plants that have been studied for disease control include Corymbia citriodora Hill \& Johnson (syn. Eucalyptus citriodora Hook). Some studies using the aqueous extract of $C$. citriodora have indicated the potential of this alternative control of plant diseases. Bonaldo et al. (3) showed inhibition of spore germination and appressorium formation of Colletotrichum lagenarium by using the aqueous extract of $C$. citriodora. Bonaldo et al. (2) verified that the crude aqueous extract of $C$. citriodora was capable of inducing phytoalexin synthesis in soybean and sorghum. Moreover, the aqueous extract significantly reduced the size of lesions caused by Colletotrichum lagenarium on cucumber plants.

Therefore, this study aimed to evaluate the effect of the aqueous extract of C. citriodora on the protection of cucumber, C. lagenarium, associated with induction of enzymes related to defense, helping clarify the involved mechanisms.

\section{MATERIAL AND METHODS}

The leaves of $C$. citriodora were obtained from the garden of medicinal plants at "Universidade Estadual de Maringá"/Paraná State, and the aqueous crude extract with $20 \%$ plant material was obtained according to Bonaldo et al. (3). For this purpose, fresh leaves of $C$. citriodora were collected, weighed and ground in a blender with distilled water at a ratio of $200 \mathrm{~g}$ plant material to $1000 \mathrm{~mL}$ water. This aqueous extract was then passed through gauze and filtered through Whatman filter paper pore size 41 . The extract was centrifuged at $20,000 \mathrm{~g}$ for $20 \mathrm{~min}$ to separate insoluble compounds. The supernatant, regarded as aqueous extract (AE), was filtered through a Millipore membrane $0.45 \mu \mathrm{m}$ pore size. The precipitate was resuspended in water. The aqueous extract, autoclaved or not, in addition to the precipitate, was evaluated for protective activity and induction of defense enzymes in cucumber. Controls were distilled water and the plant activator acibenzolar-S-methyl (50 mg a.i. $\left.\mathrm{L}^{-1}\right)$ (ASM).

The plant pathogenic fungus, Colletotrichum lagenarium, was isolated in water-agar medium $2 \%$ from symptomatic leaves of cucumber collected from the city of Marechal Candido Rondon-PR. Pure cultures of the fungus were obtained and transferred to potato- dextrose-agar (PDA) medium in Petri dishes which were maintained at $25^{\circ} \mathrm{C}$ under constant fluorescent light. To induce sporulation, they were transferred from agar-water medium to oatmeal-agar culture medium and subsequently incubated in Petri dishes at $23^{\circ} \mathrm{C}$ under black light (wavelength band around $320 \mathrm{~nm}$ ) (8). Plants were inoculated by

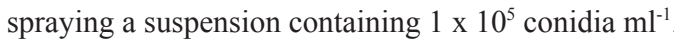

Tests were conducted on cucumber plants and seedlings to assess protection and induction of enzymes related to defense by means of treatment with $C$. citriodora AE. Tests on cucumber plants were conducted to evaluate the local or systemic activity of the AE according to the methodology employed by Di Piero (8) with some modifications. Cucumber plants were cultivated in 2-liter pots containing a mixture of soil, organic matter and sand at the ratio 2:2:1 (v:v:v), autoclaved for one hour at $120^{\circ} \mathrm{C}$. Cucumber seeds were sown in pots that were kept in a greenhouse heated to $27 \pm 2^{\circ} \mathrm{C}$ with one plant per pot. The plants were used in bioassays when they presented two true leaves. Treatments were applied by spraying on the first true leaf. Simultaneously, and at 24, 48, 72 and 96 hours after treatment application, the treated leaves, as well as the untreated second true leaf, were inoculated with $C$. lagenarium. For this group of plants, disease severity was assessed by determining the percentage of diseased leaf area at 10 days after inoculation, using the software Quant (26). For another group of plants subjected to the same treatment, instead of inoculation with the pathogen, 10 leaf discs with a diameter of $1.2 \mathrm{~cm}$ each were collected. These leaf discs were weighed and stored at $-20^{\circ} \mathrm{C}$ for peroxidase activity analysis. The effect of distilled water and $20 \%$ aqueous extract was evaluated.

These tests were conducted according to the methodology proposed by Di Piero (8) with some modifications. Therefore, cucumber seeds were sown in trays with 128 cells containing commercial substrate and kept in a heated greenhouse at a temperature of $27 \pm 2^{\circ} \mathrm{C}$. Six days after sowing, the cotyledons of each seedling were sprayed with treatments and kept in a greenhouse. Three tests were conducted on cucumber seedlings. In the first trial, autoclaved $\mathrm{AE}$, non-autoclaved $\mathrm{AE}$ and precipitation were evaluated. In the second trial, AE concentrations of $1,5,10,15$ and $20 \%$ were assessed. In the third test, the effects of AE in one or two applications were tested; the second application was at three days after the first one. In these tests, severity of anthracnose and defense and enzyme induction were evaluated. Therefore, in one group of plants, inoculation was carried out with the pathogen and in another group samples were collected for enzyme activity at 72 hours after treatment or 72 hours after the second application. Controls constituted of distilled water samples and $\mathrm{ASM}\left(50 \mathrm{mg}\right.$ i.a. $\left.\mathrm{L}^{-1}\right)$ (applied only once).

For the analysis of enzyme activity, leaf tissue samples stored at $-20{ }^{\circ} \mathrm{C}$ were ground and homogenized in $4 \mathrm{ml}$ of $0.01 \mathrm{M}$ phosphate buffer ( $\mathrm{pH}$ 6.0) containing 1\% (w/w) PVP (polyvinylpyrrolidone), in a porcelain mortar. The homogenate was centrifuged at $20,000 \mathrm{~g}$ for $25 \mathrm{~min}$ at $4{ }^{\circ} \mathrm{C}$. The supernatant (enzyme extract) was used for determination of protein content and enzyme activity. All used materials were kept under refrigeration. Total protein content was determined according to the Bradford method (4). Results were expressed as mg protein $^{-1} 1-\mathrm{ml}$ sample.

Peroxidase activity in the samples was determined spectrophotometrically based on the conversion of guaiacol into tetraguaiacol at $470 \mathrm{~nm}$ (16). Results were expressed as absorbance units at $470 \mathrm{~nm} \mathrm{~min}^{-1} \mathrm{mg}$ protein ${ }^{-1}$. The activity of polyphenol oxidase (PPO) was determined according to the methodology proposed by Duangmal \& Apenten (9), which consists in quantifying the oxidation of catechol converted into quinone, reaction mediated by the polyphenol oxidase enzyme. Results were expressed as absorbance $\mathrm{min}^{-1} \mathrm{mg}^{-1}$ protein. 
The activity of phenylalanine ammonia-lyase was determined according to the methodology described by Umesha (25), in which the results were plotted on the standard curve to trans-cinnamic acid and expressed as milligrams of trans-cinnamic acid $\mathrm{h}^{-1} \mathrm{mg}_{\text {protein }}{ }^{-1}$. The activity of $\beta$-1,3-glucanase was determined based on the colorimetric quantification of reducing sugars released from laminarin, according to the methodology proposed by Vogelsang \& Barz (29). Values were expressed as mg equivalent glucose $\mathrm{h}^{-1} \mathrm{mg}$ protein ${ }^{-1}$. The activity of chitinase was determined based on the release of soluble fragments of "CM-chitin-RBV" (30) from carboxymethylated chitin marked with bright violet remazol ("Carboxymethyl-Chitin-Remazol Brilliant Violet”). Results were expressed as absorbance $\mathrm{min}^{-1} \mathrm{mg}^{-1}$ protein units.

Results from the bioassays were subjected to analysis of variance and the treatment means were analyzed according to Tukey's test at 5\% probability. Analyses were performed by using the computer system SISVAR, version 5.0 (System-statistic UFLA analysis).

\section{RESULTS AND DISCUSSION}

In cotyledons of cucumber, ASM, AE and autoclaved AE significantly reduced the severity of anthracnose by $49.6,37.6$ and $39.6 \%$, respectively, compared to control treated with distilled water (Figure 1).

The resuspended precipitate resulting from centrifugation of the aqueous extract at 20,000 $\mathrm{g}$ for $30 \mathrm{~min}$ had no effect on the disease severity or on the activity of enzymes related to plant defense for both studied pathosystems, possibly indicating the absence of active compounds in this fraction.

With respect to peroxidase activity, ASM and AE promoted significant increase in the activity of this group of enzymes, which was 83.6 and $67.2 \%$, respectively, compared to the water control. The autoclaved $\mathrm{AE}$ had lower activity than the non-autoclaved extract but still exceeded the water control by $14.6 \%$, indicating partial loss of activity due to autoclaving. A large number of authors consider peroxidases accumulation a biochemical marker of induced resistance in cucumber (6), although the correlation between the activity of these enzymes and the protection of plants is not always clear.

Dalisay \& Kuc (7) demonstrated that peroxidases have no direct relation with resistance induction in cucumber and therefore could not be used as a resistance marker for that pathosystem, as suggested by other authors (6). However, the role of peroxidases in defense mechanisms such as lignin formation by the polymerization of phenols is proven and changes in peroxidase activity are also expected to involve changes in the activity of other enzymes present in the same metabolic pathway. Thus, Boava et al. (1) noted that peroxidases are used in the study of resistance induction, not as a marker, but as one of the many defense responses expressed by plants.

With respect to $\beta$-1,3-glucanases, $\mathrm{AE}$ also expressed activity. In cucumber cotyledons, both ASM and EA promoted an increase in the enzyme, which was 139.0 and $122.7 \%$, when compared to the distilled water control. Di Piero (8), studying the potential of Lentinula edodes and Agaricus blazei mushrooms in the induction of resistance in cucumber, did not find induction on glucanase activity. However, Ji \& Kuc (13) showed that an acidic isoform of $\beta$-1,3-glucanase participates in resistance in cucumber.

For chitinase, none of the treatments caused a significant increase in the activity of this enzyme. These results suggest that the action of AE on C. citriodora cucumber does not involve, at least significantly, the activity of this enzyme, although the plant activator has not promoted a significant increase in the activity either.

As for polyphenol oxidase activity, only the ASM plant activator promoted a significant increase in the activity of this enzyme. On the other hand, the result of AE did not differ statistically from that obtained for ASM and expressed a sensitive activity over this enzyme, higher than that presented by the precipitate. Silva et al. (23), evaluating microbiolized bean seeds with fluorescent Pseudomonas, obtained metabolic changes in bean leaves with increased content of total soluble protein and polyphenol oxidase activity. The increase in polyphenol oxidase and peroxidase activity in plants has also been reported with other extracts and vegetable derivatives, such as tinctures $(17,28)$.

ASM and AE stimulated the synthesis of phenylalanine ammonialyase (FAL) in 16.2 and $18.5 \%$, respectively. Kuhn (14) noted that in bean plants treated with Bacillus cereus and ASM, phenylalanine ammonia lyase activity was not changed due to the inductors, suggesting that the phenylpropanoid pathway did not suffer alterations. Increase in FAL is associated with a reduction in the severity of some plant diseases. This was not observed by Silva et al. (22), who detected no changes in FAL activity in seed treatment with Bacillus cereus in tomato; however, high peroxidase activity was emphasized. The use of neem (Azadirachta indica) extract promoted an increase in the activity of polifenol oxidase, FAL and peroxidase in carrots, indicating a resistance-inducing effect (17). Increase in FAL activity was also observed after inoculation of C. lagenarium in melon (10).

As for the evaluation of local or systemic effect of AE, in treated leaves there was a reduction in the severity of anthracnose over 72 and 96 hours, in comparison to leaves that received only water (Figure 2), expressing local protective effect. For the second leaf, which did not receive the treatment, there was no significant difference in protection between leaves treated with $\mathrm{AE}$ or just water. Similar results were obtained with respect to peroxidase activity. In this case, the effect of AE was more evident at 48 hours after treatment, already showing induction of peroxidases by AE. Similarly, for peroxidases, leaves that did not receive treatment showed no significant difference between treatments.

Activity of AE only in the treated leaves suggests priority for local action of the extract, with no or limited systemic action under the conditions of analysis of this study. According to a large number of authors, induced resistance can only be local or systemic (27). In cases where rhizobacteria are inducing agents, usually there is systemicity (19). The antifungal activity against $C$. lagenarium presented by AE of $C$. citriodora on spore germination and appressorium formation reported by Bonaldo et al. (3) may contribute to reduce the severity of anthracnose in cucumber. These authors also evaluated the number and size of lesions of C. lagenarium on the first and second leaf of cucumber plants; only the first leaf received treatment with aqueous extract of C. citriodora, while the untreated leaf did not obtain a reduction in disease, suggesting the absence of systemic effect on cucumber by aqueous extract of $C$. citriodora. Peroxidase induction in treated cucumber leaves was relevant to the reduction in the disease severity, corroborating the statement that peroxidase accumulation is closely related in inducing resistance in cucumber plants (6).

Di Piero (8) evaluated the effect of aqueous extract of the mushroom Lentinula edodes on cucumber plants and observed an increase in local and systemic activity of peroxidases on the ninth and twelfth day after treatment, respectively (the third and sixth day after inoculation with Colletotrichum lagenarium). The potential local protective effect on cucumber leaves by the extract of $C$. citriodora was reported by Bonaldo et al. (3). Similarly, resistance of melon plants (Cucumis melo L.) 

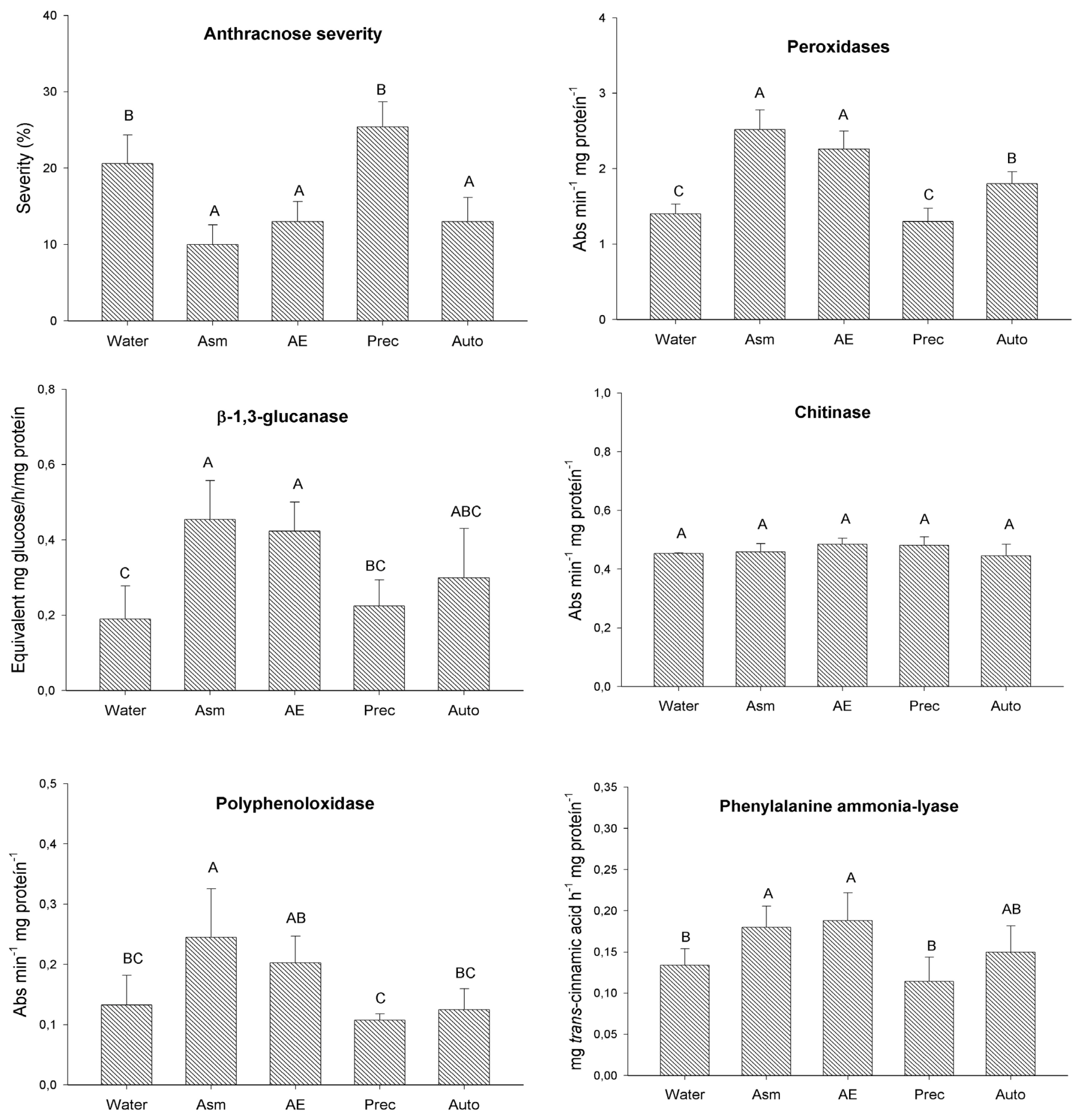

Figure 1. Severity of anthracnose and induction of defense enzymes in cucumber cotyledons treated with aqueous extract (20\%) of Corymbia citriodora. AE: aqueous extract; Prec: precipitate of the centrifugation of AE resuspended in water; Auto: autoclaved AE. Control: distilled water and acibenzolar-S- methyl (50 $\mathrm{mg}$ a.i. $\left.\mathrm{L}^{-1}\right)(\mathrm{ASM})$. The bars represent the mean \pm standard error. Means followed by the same letters do not differ according to Tukey's test at $5 \%$ probability.

against $C$. lagenarium is associated with localized and intense release of reactive oxygen $(10)$.

As to the effect of AE concentration, an increase was observed in peroxidase activity at concentrations of $5 \%$ (Figure 3 ). The increase in $\mathrm{AE}$ activity from $5 \%$ was relevant to reducing the severity of anthracnose, which was also observed at concentrations of $5 \% \mathrm{AE}$. The concentration of elicitors in $\mathrm{AE}$ at concentrations lower than 5\% may be not sufficient to trigger defense mechanisms in cucumber.

One of the criteria is to confirm if the resistance displayed by the plant was induced and there was no magnitude of expressing resistance 

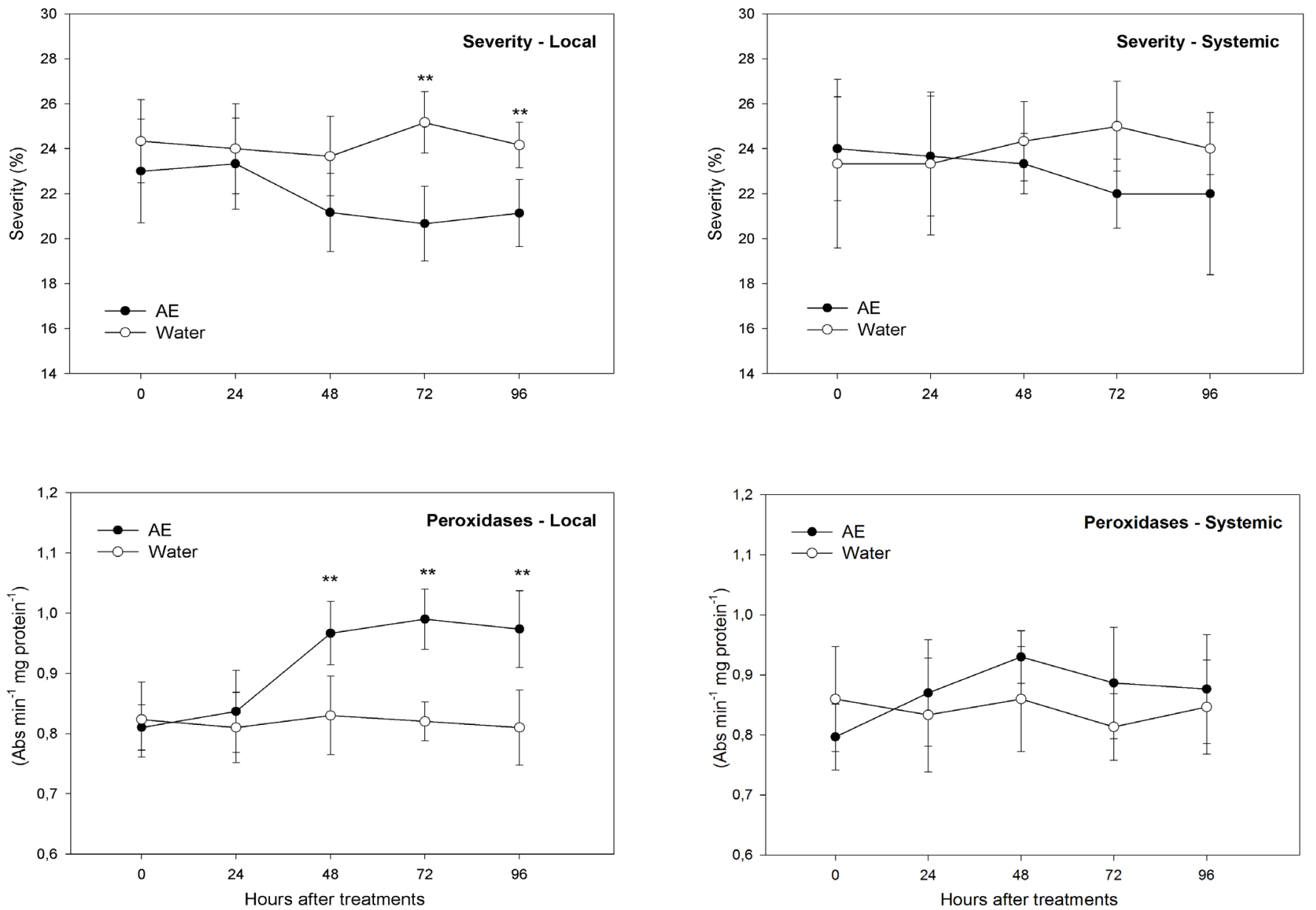

Figure 2. Effect of applying the aqueous extract (AE) of Corymbia citriodora on the peroxidase activity in cucumber plants for different time intervals between the inductor treatment and inoculation with the pathogen. Local effect: first treated trefoil; systemic effect: according to untreated trefoil. Bars represent the standard error of the mean. ** Significant according to Tukey's test at $5 \%$ probability.
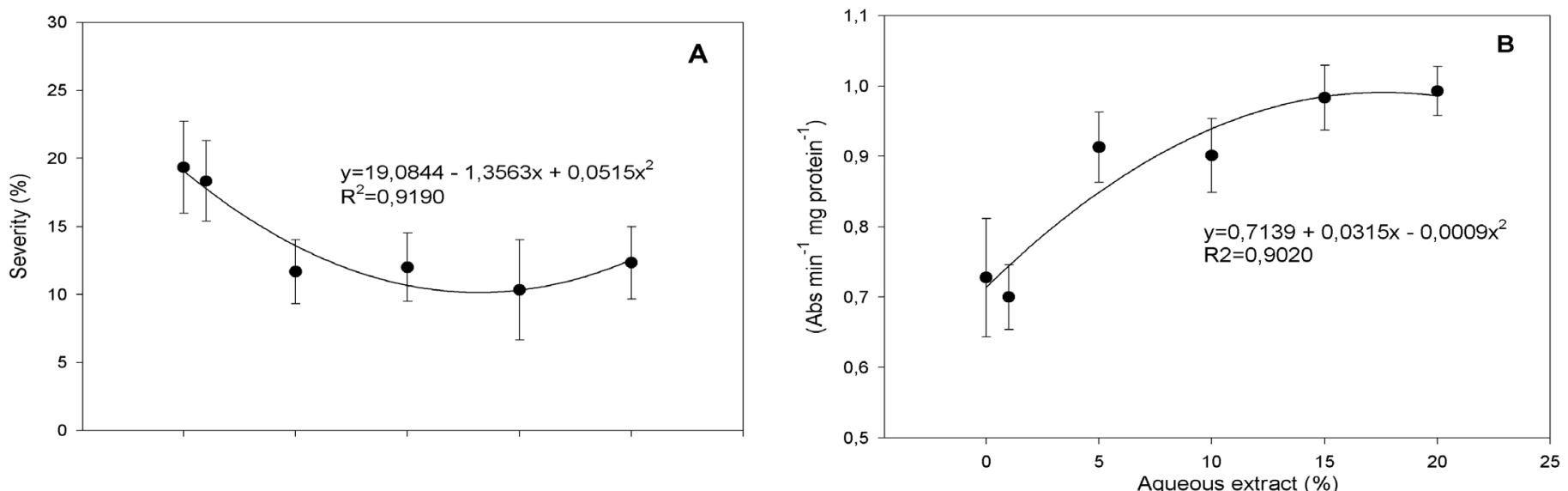

Figure 3. Severity of anthracnose (A) and peroxidases activity (B) in cotyledons of cucumber treated with different concentrations of aqueous extract of Corymbia citriodora. Bars represent the standard error of means. 

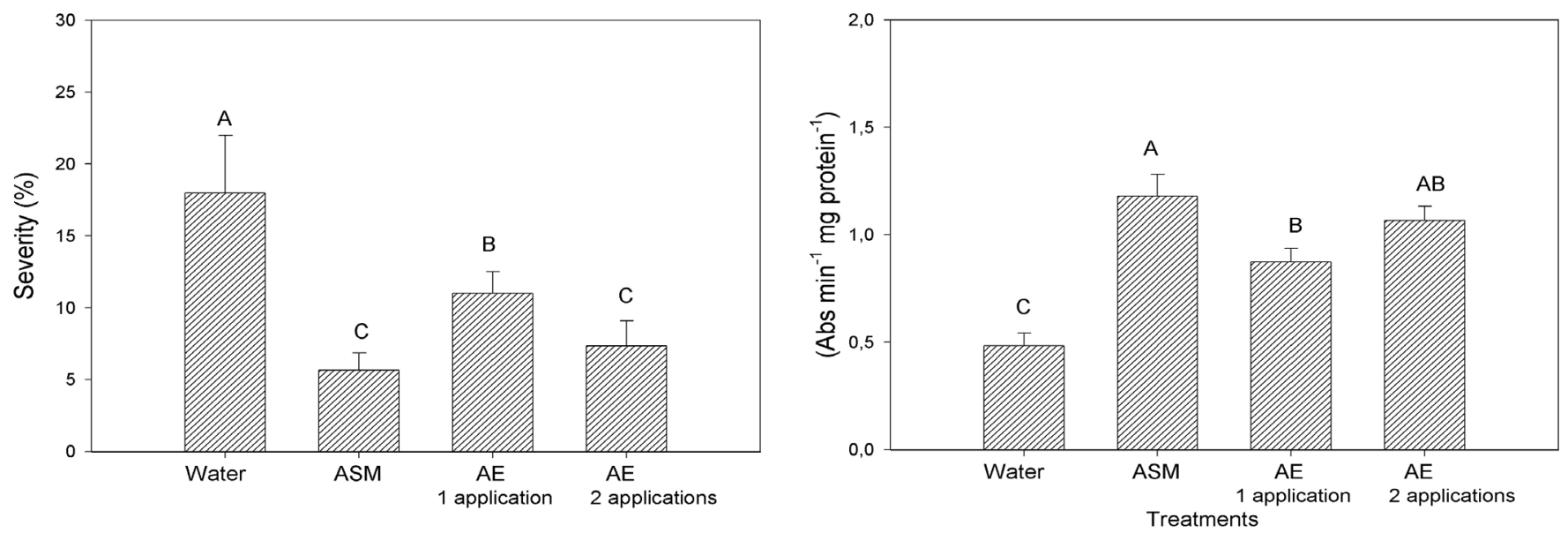

Figure 4. Severity of anthracnose and peroxidases activity in cucumber cotyledons treated once or twice ( 3 days or 3 and 6 days before inoculation or sampling, respectively) with aqueous extract (AE) (20\%) of Corymbia citriodora. Control: distilled water and acibenzolar-S- methyl (50 mg a.i. L- 1 ). Means followed by the same letters do not differ according to Tukey's test at $5 \%$ probability.

and increasing amounts of the applied inductor (19). However, if an inductor is biotic, there is the need for a minimum number of cells to be in contact with the plant to be induced but once this resistance is expressed it increases the amount of inducer cells which does not correspond to an increase in resistance.

AE, when applied twice in cucumber cotyledons (one application at three days and another application at six days before inoculation with the pathogen), caused a significant reduction in the severity of anthracnose with respect to only one application (three days prior to inoculation). This reduction in the disease severity was similar to that achieved by the ASM activator applied three days prior to inoculation. For the peroxidase enzyme, there was no difference between the numbers of applications, but again two applications permitted results similar to that of ASM (Figure 4).

The fact that two applications have helped control the disease and have not induced significant increase in peroxidase activity may have been favored by greater accumulation of antifungal compounds present in the $\mathrm{AE}$ on the plant surface. Although there are few studies on the use of antifungal compounds of $C$. citriodora AE on plant disease control, the antifungal activity of Eucalyptus citriodora ( $\sin$. C. citriodora) AE on $C$. lagenarium has been reported by Bonaldo et al. $(2,3)$, as well as extracts from other plant species (5). Iriti \& Faoro (12) observed that applying ASM two or three times on beans, before inoculation with Uromyces appendiculatus, showed 99.6 and 100\% reduction in pustules, respectively.

Overall, the pathosystem cucumber and C. lagenarium presented significant results in bioassays, confirming the information that this is an appropriate and interesting pathosystem for evaluation in resistance induction tests. The results suggest the effect of $\mathrm{AE}$ in inducing local resistance in cucumber with induction of peroxidases and $\beta-1,3-$ glucanases.

\section{REFERENCES}

1. Boava, L.P.; Kuhn, O.J.; Pascholati, S.F.; Di Piero, R.M.; Furtado, E.L. Efeito de indutores bióticos e abióticos na atividade de quitinase e peroxidase e no controle da ferrugem causada por Puccinia psidii em eucalipto. Summa Phytopathologica, Botucatu, v.36, n.2, p.168-172, 2010.

2. Bonaldo, S.M.; Schwan-Estrada, K.R.F.; Stangarlin, J.R.; Cruz, M.E.;
Fiori-Tutida, A.C.G. Contribuição ao estudo das atividades antifúngica e elicitora de fitoalexinas em sorgo e soja por eucalipto (Eucalyptus citriodora). Summa Phytopathologica, Botucatu, v.33, n.4, p.383-387, 2007.

3. Bonaldo, S.M. Schwan-Estrada, K.R.F.; Stangarlin, J.R.; Tessman, D.J.; Scapim, C.A. Fungitoxicidade, atividade elicitora de fitoalexinas e proteção de pepino contra Colletotrichum lagenarium pelo extrato aquoso de Eucalyptus citriodora. Fitopatologia Brasileira, Brasília, v.29, n.2, p.128-134, 2004.

4. Bradford, M.A. A rapid and sensitive method for the quantitation of microgram quanties of protein utilizing the principle of protein-dye binding. Analytical Biochemistry, New York, v.72, n.1, p.248-254, 1976.

5. Chen, Y; Dai, G. Antifungal activity of plant extracts against Colletotrichum lagenarium, the causal agent of anthracnose in cucumber. Journal of the Science of Food and Agriculture, Chichester, v.92, n.9, p.1937-1943, 2012.

6. Conti, G.C.; Bassi, M.; Maffi, D.; Violini, G.; Magnani, L.; Gatti, L. Induced systemic resistance against Sphaeroteca fuliginea in cucumber: efficiency of Tobaco necrosis virus and copper sulphate in eliciting defence reactions. Journal of Phytopatology, Berlin, v.140, n.2, p.123-132, 1994.

7. Dalisay, R.F.; Kuc, J.A. Persistence of induced resistance and enhanced peroxidase and chitinase activities in cucumber plants. Physiological and Molecular Plant Pathology, London, v.47, n.5, p.315-327, 1995.

8. Di Piero, R.M. Potencial de cogumelos Lentinula edodes (Shiitake) e Agaricus blazei (cogumelo-do-sol) no controle de doenças em plantas de pepino, maracujá e tomate, e purificação parcial de compostos biologicamente ativos. 2003. 157p. Tese (Doutorado em Agronomia)-Escola Superior de Agricultura "Luiz de Queiroz", Universidade de São Paulo, Piracicaba.

9. Duangmal, K.; Apenten, R.K.O. A comparative estudy of poliphenoloxidases from taro (Colocasia esculenta) e potato (Solanum tuberosum var. Romano). Food Chemistry, Barking, v.64, n.3, p.351-359, 1999.

10. Ge, Y.; Bi, Y.; Guest, D.I. Defense responses in leaves of resistant and susceptible melon (Cucumis melo L.) cultivars infected with Colletotrichum lagenarium. Physiological and Molecular Plant Pathology, London, v.81, n.1, p.13-21, 2013.

11. Heldt, H.W. Plant Biochemistry. 3.ed. San Diego: Elsevier Academic Press. 2005. 630p.

12. Iriti, M.; Faoro, F. Benzothiadiazole (BTH) induces cell-death independent resistance in Phaseolus vulgaris against Uromyces appendiculatus. Journal of Phytopathology, Berlin, v.151, n.3, p.171-180, 2003.

13. Ji, C.; Kuc, J. Purification and characterization of na acidic $\beta$-1,3-glucanase from cucumber and its relationship to systemic disease resistance induced by Colletotrichum lagenarium and Tobacco necrosis vírus. Molecular Plant-Microbe Interaction, Palo Alto, v.8, n.6, p.899-905, 1995.

14. Kuhn, O.J. Indução de resistência em feijoeiro (Phaseolus vulgaris) por acibenzolar-S-metil e Bacillus cereus: aspectos fisiológicos, bioquímicos e parâmetros de crescimento e produção. 2007. 140p. Tese (Doutorado em Agronomia)-Escola Superior de Agricultura "Luiz de Queiroz", Universidade de São Paulo, Piracicaba, 
15. Kurabachew, H.; Wydra, K. Induction of systemic resistance and defense-related enzymes after elicitacion of resistance by rhizobacteria and silicone application against Ralstonia solanacearum in tomato (Solanum lycopersicum). Crop Protection, Oxford, v.57, p.1-7, 2014.

16. Lusso, M.F.G.; Pascholati, S.F. Activity and isoenzymatic pattern of soluble peroxidades in maize tissues after mechanical injury or fungal inoculation. Summa Phytophatologica, Botucatu, v.25, n.3, p.244-249, 1999.

17. Ojaghian, M.R., Wang, L.; Cui, Z.Q.; Yang, C.; Zhongyun, T.; Xie, G.L. Antifungal and SAR potential of crude extracts derived from neem and ginger against storage carrot rot caused by Sclerotinia sclerotiorum. Industrial Crops and Products, Amsterdam, v.55, n.2, p.130-139, 2014.

18. Oliveira, M.D.M.; Varanda, C.M.R.; Félix, M.R.F. Induced resistance during the interaction pathogen $\mathrm{x}$ plant and the use of resistance inducers. Phytochemistry Letters, Amsterdam, v.15, p.152-158, 2016.

19. Romeiro, R.S. Indução de resistência em plantas a patógenos. In: Pascholati, S.F.; Leite, B.; Stangarlin, J.R.; Cia, P. (Ed.). Interação planta-patógeno: fisiologia, bioquímica e biologia molecular. Piracicaba: FEALQ, 2008. cap.13, p.411-432.

20. Roberti, R.; Galletti, S.; Burzi, P.L.; Righini, H.; Cetrullo, S.; Perez, C. Induction of defense responses in zucchini (Cucurbita pepo) by Anabaena sp. water extract. Biological Control, Maryland Heights, v.82, p.61-68, 2015.

21. Schwan-Estrada, K.R.F.; Stangarlin, J.R.; Cruz, M.E.S. Uso de plantas medicinais no controle de doenças de plantas. Fitopatologia Brasileira, Brasília, v.8, p.54-56, 2003.

22. Silva, E.G.; Moura, A.B.; Bacarin, M.A.; Deuner, C.C. Alterações metabólicas em plantas de feijão originadas de sementes microbiolizadas por Pseudomonas sp. e inoculadas com Xanthomonas axonopodis pv. phaseoli.
Summa Phytopathologica, Botucatu, v.35, n.2, p.98-104, 2009.

23. Silva, H.S.A.; Romeiro, R.S.; Macagnan, D.; Halfeld-Vieira, B.A.; Pereira, M.C.B.; Mounteer, A. Rhizobacterial induction of systemic resistance in tomato plants: non specific protection and increase enzyme activities. Biological Control, Maryland Heights, v.29, n.2, p.288-295, 2004.

24. Stangarlin, J.R.; Kuhn, O.J.; Schwan-Estrada, K.R.F. Controle de doenças de plantas por extratos de origem vegetal. Revisão Anual de Patologia de Plantas, Passo Fundo, v.16, p.265-304, 2008.

25. Umesha, S. Phenylalanine ammonia lyase activity in tomato seedlings and its relationship to bacterial canker disease resistance. Phytoparasitica, Israel, v.34, n.1, p.68-71, 2006.

26. Vale, F.X.R.; Fernandes Filho, E.I.; Liberato, J.R. Quantificação de doenças - Quant versão 1.0.1. Viçosa: UFV. 2001. Software.

27. Van Loon, L.C. Induced resistance in plants and the role of pathogenesis related proteins. European Journal of Plant Pathology, Dordrecht, v.103, n.9, p.753-765, 1997.

28. Vigo, S.C.; Maringoni, A.C.; Camara, R.C.; Lima, G.P.P. Ação de tinturas e óleos essenciais de plantas medicinais sobre o crestamento bacteriano comum do feijoeiro e na produção de proteínas de indução de resistência. Summa Phytopathologica, Botucatu, v.35, n.4, p.293-304, 2009.

29. Vogelsang, R.; Barz, W. Purification, characterization and differential hormonal regulation of a $\beta$-1,3-glucanase and chitinases from chickpea (Cicer arientinum L.). Planta, Berlin, v.189, n.1, p.60-69, 1993.

30. Wirth, S.J.; Wolf, G.A. Dye-labelled substrates for the assay and detection of chitinase and lysozyme activity. Journal of Microbiological Methods, Amsterdam, v.12, n.3/4, p.197-205, 1990. 